\title{
Article \\ Effect of Cosmetics Use on the In Vitro Skin Absorption of a Biocide, 1,2-Benzisothiazolin-3-one
}

\author{
Yoonjung Huh ${ }^{1}$, Do-Hyeon Lee ${ }^{2}$, Dalwoong Choi ${ }^{2, *}$ and Kyung-Min Lim ${ }^{1, * \mathbb{D}}$ \\ 1 College of Pharmacy, Ewha Womans University, Seoul 03760, Korea; huhlisa@naver.com \\ 2 Transdisciplinary Major in Learning Health Systems, Department of Health and Safety Convergence Science, \\ Korea University, Seoul 02481, Korea; key6855@naver.com \\ * $\quad$ Correspondence: dwlove@korea.ac.kr (D.C.); kmlim@ewha.ac.kr (K.-M.L.); Tel.: +82-2-3277-3055 (K.-M.L.)
}

check for updates

Citation: Huh, Y.; Lee, D.-H.; Choi, D.; Lim, K.-M. Effect of Cosmetics Use on the In Vitro Skin Absorption of a Biocide, 1,2-Benzisothiazolin3-one. Toxics 2022, 10, 108. https:// doi.org/10.3390/toxics10030108

Academic Editor: Jeroen

Vanoirbeek

Received: 27 January 2022

Accepted: 21 February 2022

Published: 24 February 2022

Publisher's Note: MDPI stays neutral with regard to jurisdictional claims in published maps and institutional affiliations.

Copyright: () 2022 by the authors. Licensee MDPI, Basel, Switzerland. This article is an open access article distributed under the terms and conditions of the Creative Commons Attribution (CC BY) license (https:/ / creativecommons.org/licenses/by/ $4.0 /)$.

\begin{abstract}
Benzisothiazolin-3-one (BIT) is a commonly used organic biocide containing an isothiazolone ring. However, it may have adverse effects on human health and its risk needs to be properly evaluated. Dermal exposure is the main route of BIT exposure, and co-exposed substances may affect its absorption. The dermal permeation profile of BIT has not been well-studied. This study aimed to investigate the dermal permeation profiles of BIT with or without cosmetic use. Dermal permeation profiles of BIT were investigated after infinite- $\left(100 \mu \mathrm{g} / \mathrm{cm}^{2}\right)$, or a finite-dose $\left(10 \mu \mathrm{g} / \mathrm{cm}^{2}\right)$ application with or without cosmetics using a minipig skin and Strat- $\mathrm{M}^{\circledR}$, an artificial membrane. A cream, lotion, and essence (namely, face serum) were pre-treated as representative cosmetics on minipig skin for $30 \mathrm{~min}$, with BIT treatment afterward. After the treatment, BIT left on the skin surface was collected by cotton swabbing, BIT in the stratum corneum, by sequential tape stripping, and BIT retained in the remaining skin was extracted after cutting the skin into pieces before LC-MS/MS analysis. When an infinite dose was applied, permeation coefficients $\left(\mathrm{K}_{\mathrm{p}}, \mathrm{cm} / \mathrm{h}\right)$ for minipig skin and Strat- $\mathrm{M}^{\circledR}$ were $2.63 \times 10^{-3}$ and $19.94 \times 10^{-3}$, respectively, reflecting that skin permeation was seven to eight times higher in Strat- $\mathrm{M}^{\circledR}$ than in the minipig skin. BIT, in the presence of cosmetics, rapidly permeated the skin, while the amount in the stratum corneum and skin deposit was reduced. We performed a risk assessment of dermally applied BIT in the absence or presence of cosmetics by calculating the skin absorption rate at $10 \mathrm{~h}$ based on the toxicological data from several references. The risk level was higher in the presence of essence as compared to lotion, which was higher than cream, which was higher than the control (non-treated). However, all of the margins of safety values obtained were greater than 100, suggesting that BIT is safe for use in dermally exposed consumer products. We believe that this research contributes to a greater understanding of the risk assessment of isothiazolinone biocides.
\end{abstract}

Keywords: 1,2-Benzisothiazolin-3-one; isothiazolinones; skin absorption; cosmetics; risk assessment

\section{Introduction}

Isothiazolone biocides are widely used in a variety of industrial water treatment applications to control microbial growth and biofouling [1]. They have also been recommended as preservatives in leave-on and rinse-off cosmetics, aqueous household products (e.g., water-based paints and cleaning and washing agents), and diverse manufactured goods (e.g., paints, glues, adhesives, detergents, inks, polishes, and leathers) [2]. 1,2Benzisothiazolin-3-one (BIT) is one of the most commonly used preservatives in isothiazolinones. In the Danish Product Register Database (PROBAS), thousands of products have been registered as containing isothiazolinones, and BIT (contained in over 985 different products) is the most widely used isothiazolinone, especially in paints and varnishes [3].

The physical, chemical, and biological reactions of most chemicals are determined by their chemical structure [4]. Like all isothiazolinones, BIT is a heterocyclic compound characterized by a nitrogen and sulfur-containing aromatic ring (1,2-thiazol-3-one), rendering 
it electrophilic [5]. Isothiazolinones can diffuse across bacterial cell membranes and the cell wall of fungi [6]. In the intracellular media, the electron-deficient sulfur of the N-S bond can react with the nucleophilic groups of the cellular components, such as the thiols of cysteines in active sites, blocking their enzymatic activity and ultimately causing cellular death $[6,7]$.

With the widespread use of isothiazolinones, there is an increasing concern about unwanted side effects, as biocides could harm human health and the environment [8]. Isothiazolinones cause airborne contact dermatitis, respiratory symptoms, including acute asthma, and systemic allergic contact dermatitis [3]. BIT may also provoke allergic skin reactions in humans [9]. BIT is not included in Annex 5 of the Cosmetics Regulation $1223 / 2009$ of the EU, a positive list containing the preservatives that are allowed in cosmetic products, while it is still allowed for use in cosmetics in the United States and Canada [10]. Additionally, in the United States, no federal regulations restrict the use of BIT except for one regarding the manufacture of rubber gloves that contact food items, limiting it to below $0.05 \%$ in latex solids [11]. Indeed, a study demonstrated that BIT is contained at $0.0009 \%$ and $0.0027 \%$ for sunscreen and dish soap samples in in the United States [12]. Additionally, some illegal uses of isothiazolinones in personal care products (PCP) have been reported in several studies $[10,13]$, so people may be unwittingly exposed to BIT in daily life.

BIT exposure occurs through a variety of routes, including oral, inhalation, or dermal. Oral exposure plays a minor role, exception for children mouthing contaminated objects, because it cannot be added to food or food-related products. Inhalation exposure of BIT may be more harmful [14], but it is expected to be negligible except for the inhalation of aerosols containing BIT, since BIT has relatively low vapor pressure $\left(6.3 \times 10^{-5} \mathrm{~Pa}\right.$ at $20^{\circ} \mathrm{C}$ ) [15]. Therefore, dermal exposure is the main route of human exposure to BIT. The skin is the largest organ of the body and is multilayered and highly differentiated, with a total area of about 20 square feet [16]. The various layers that form the epidermis and dermis are composed of living tissue surrounding the body. For chemicals to absorb into the bloodstream or the lymphatic system through the skin, they must pass through the stratum corneum (SC), the rate-limiting step for skin permeation [17]. Many factors play important roles in dermal absorption, including the molecular weight and charge of the chemical ingredient, lipophilicity of the formulation, thickness of keratin and constituents (dependent on the body part), duration of exposure, area of the skin onto which a chemical was applied, the concentration of application, other substances pretreated on the skin, and other factors [18]. Drugs and chemicals that are suitable for transdermal delivery have a $\operatorname{LogP}>1.5$ and a molecular weight $<500 \mathrm{Da}$ [19]. BIT has a small molecular weight (MW 151.18) and has a $\log p$ value that is relatively close to $1\left(0.76\right.$ at $\left.30^{\circ} \mathrm{C}, \mathrm{pH} 7\right)$, allowing it to readily permeate the skin barrier for systemic absorption.

The use of skin-care products, including cream, lotion, and essence, is one of the significant factors affecting dermal absorption. Many of these products contain chemicals that enhance dermal penetration [19]. These enhancers can remain on the skin and incorporate into the skin surface. This, in turn, may alter the lipid domain of the skin by interacting with barrier proteins, thereby increasing the partitioning of chemicals to the SC [20]. Mixtures of dermal penetration-enhancing chemicals can act synergistically to increase the dermal penetration of small lipophilic molecules by up to 100-fold [21]. Skincare products have been increasingly used in recent years. Furthermore, since the COVID-19 pandemic, the use of hand sanitizers has increased prominently, and its market has reached 200 million US dollars a year in the United States [22]. Hoffman et al. showed that the dermal absorption of harmful substances in several products increases after the use of hand sanitizers [19], indicating a significant impact of skincare products on the skin penetration of harmful chemicals. However, few studies have examined the impact of cosmetics on biocide skin absorption.

The lack of experimental data on human dermal absorption of BIT is a major research gap hindering an accurate exposure assessment. Although the skin permeability coefficient value $\left(\mathrm{K}_{\mathrm{p}}\right)$, which is a key parameter in estimating dermal absorption, has been calculated 
for BIT using a mathematical model [10], it has not yet been experimentally verified. The aim of this paper was to investigate the dermal absorption of BIT using two in vitro dermal models, namely, minipig skin and Strat- $\mathrm{M}^{\circledR}$. Porcine skin has been officially recognized as a replacement for human skin for skin permeation studies [23] and it has also been used in various dermatological studies [24]. Strat- $\mathrm{M}^{\circledR}$ is a multilayered synthetic membrane (300 $\mu \mathrm{m}$ thickness) similar to skin and made up of several tightly-packed layers of polyester sulfone [25]. Uchida et al. evaluated the skin permeabilities of 13 compounds using Strat$\mathrm{M}^{\circledR}$ and compared them with animal skin, which found that the permeation coefficient and diffusion parameters were well-correlated [26]. We also studied the effect of skincare products (cream, lotion, and essence (or face serum)) pretreatment on the dermal absorption of BIT, and conducted a risk assessment of dermally exposed BIT with or without skincare products.

\section{Materials and Methods}

\subsection{Materials and Chemicals}

We purchased 1,2-benzisothiazolin-3-one (BIT, CAS No. 2634-33-5, purity 97\%), MEMbased culture medium, and isopropanol (2-Propanol, CAS No. 67-63-0, 99.9\%) from SigmaAldrich (St. Louis, MO, USA). Methanol (CAS No. 67-56-1, purity 99.8\%) was purchased from Junsei Chemical Co., Ltd. (Tokyo, Japan). Analytical-grade water (CAS No. 7732-18-5) was purchased from Duksan Co. (Gyeonggi-do, Korea).

\subsection{Skin Preparation}

Porcine skin $\left(1.5 \times 1.5 \mathrm{~cm}^{2}\right)$ was obtained from Apures Co. (Pyeongtaek, Gyeonggi-do, Korea). All porcine skins were obtained from the back of minipig skin, which was sacrificed for research on drug delivery. The skin was stored at $-20{ }^{\circ} \mathrm{C}$ to prevent denaturation. Frozen skins were thawed at room temperature and equilibrated for $30 \mathrm{~min}$ in 6-well plates containing $2 \mathrm{~mL}$ of MEM media before the experiment.

A Strat-M ${ }^{\circledR}$ membrane was purchased from EMD Millipore (Millipore, Burlington, MA, USA). These membranes did not require any pretreatment and were used immediately after removal from the packaging.

\subsection{Dosing Solutions}

Two different BIT concentration levels of (I) $0.05 \%(w / v)$ and (II) $0.02 \%(w / v)$ were prepared in isopropanol according to the OECD guidelines [23]. Based on the exposed surface area, a net dose of $100 \mu \mathrm{g} / \mathrm{cm}^{2}$ and $10 \mu \mathrm{g} / \mathrm{cm}^{2}$ was applied to each of the investigated skin tissues using $200 \mu \mathrm{L} / \mathrm{cm}^{2}$ (infinite dose application) of dosing solution I and $50 \mu \mathrm{L} / \mathrm{cm}^{2}$ (a finite-dose application) of dosing solution II. Isopropanol was selected as the dosing vehicle based on its ability to dissolve the test compound at the desired levels. It better mimics finite exposure due to its higher volatility [27].

To study the possible effect of skincare products on the percutaneous penetration, BIT was applied to the skin surface in a finite-dose application after the cream, lotion, and essence $\left(30 \mathrm{mg} / \mathrm{cm}^{2}\right)$ were treated for $30 \mathrm{~min}$. The skincare products were manufactured as that generally used in Korea by Dermameal Co. (Gunpo, Gyeonggi-do, Korea). The formulations are detailed in the Supplementary Materials.

\subsection{Percutaneous Absorption Assay Protocol}

A percutaneous absorption experiment was performed using a vertical diffusion cell (VDC) test system model HDT 1000 from Copley Scientific Limited (Nottingham, United Kingdom, $1.00 \mathrm{~cm}^{2}$ surface area; and stirred volume $6.5 \mathrm{~mL}$ ) in compliance with the OECD guidelines for in vitro dermal absorption testing [23]. Skin samples were mounted in standard glass Franz cells with the stratum corneum facing up and equilibrated for $30 \mathrm{~min}$. Just before the application of the test chemicals, non-invasive trans-epidermal water loss (TEWL) was measured using GPskin pro (Gpower, Inc., Seoul, Korea) to evaluate skin barrier integrity. Skins with a TEWL value of $40 \mathrm{~g} / \mathrm{m}^{2} \cdot \mathrm{h}$ or higher were excluded from 
the experiment. The tested chemicals were applied onto the skin surface in the donor compartment. A MEM-medium was used as the receptor fluid, maintained at $32 \pm 1{ }^{\circ} \mathrm{C}$ and magnetically stirred at $600 \mathrm{rpm}$. The experiment was conducted in open conditions.

At fixed time-points $(0.5,1,2,4,6,10$, and $24 \mathrm{~h})$, aliquots of the receptor fluid $(0.2 \mathrm{~mL})$ were collected from the receptor compartment and immediately replaced with fresh fluid. After $24 \mathrm{~h}$, the receptor fluid aliquot was collected, and the skin surface and donor compartment were washed thoroughly with alcohol swabs (BDTM Alcohol Swabs, Becton Dickinson Corp, Franklin Lakes, NJ, USA) three times to measure the unabsorbed dose. The tape-stripping method was used to remove the remaining formulation from the SC. The tape (Scotch $3 \mathrm{M}$ ) was cut into $2.5 \times 2.5 \mathrm{~cm}$ portions and applied to the skin surface (SC side up) after washing, pressed down with forceps, and pulled gently from the skin. This was repeated 10 times for each skin sample. The remaining skin was cut into 10 pieces using surgical scissors and placed in solvent for extraction. Receptor fluid samples, skin wash samples, tape strip samples, and skin deposit samples extracted from each step were put in $5 \mathrm{~mL}$ of (1:1) methanol: water or pure water, sonicated for an hour, and stored $\mathrm{a}-20{ }^{\circ} \mathrm{C}$ until chemical analysis. To obtain a blank matrix for each sample, only dosing vehicles without BIT were treated on the skin as per the above process. The overall schematic diagram of the absorption assay is described in Figure 1.

\subsection{Sample Extraction and Calibration Sample Preparation}

We mixed $200 \mathrm{uL}$ of the samples and $200 \mu \mathrm{L}$ of methanol in a micro-centrifuge tube on a vortex for $1 \mathrm{~min}$. After centrifugation of the mixture at $13,000 \times g$ for $10 \mathrm{~min}$, the supernatant was filtered using a $0.22 \mu \mathrm{m}$ polytetrafluoroethylene (PTFE) filter (ADVANTEC, Dublin, CA, USA).

Calibration standards were prepared at 3.125, 6.25, 12.5, 31.25, 62.5, 125, 250, and $500 \mathrm{ng} / \mathrm{mL}$ by adding a standard solution to a blank matrix of receptor fluid samples, skin wash samples, tape strip samples, and skin deposit samples. All calibration standards were extracted in the same way as the other analytes before analysis.

\subsection{Liquid Chromatography Instruments and Conditions}

The levels of BIT were measured using high-performance liquid chromatography (Agilent 1200 series HPLC; Agilent Technologies, Santa Clara, CA, USA) coupled with a triple-quadrupole mass spectrometer (EVOQ Qube ${ }^{\mathrm{TM}}$; Bruker Daltonics, Billerica, MA, USA). Separation was achieved using an Agilent ZORBAX Eclipse plus C18 column (2.1 mm $\times 50 \mathrm{~mm}, 1.8 \mu \mathrm{m})$. The mobile phase composition used in the chromatographic separation was optimized by binary mixtures of $0.1 \%$ formic acid in deionized water (solvent $\mathrm{A}$ ) and $100 \%$ methanol (solvent B). Gradient conditions were as follows: 0-5 min, 30\% B; 5-10 min, $30-100 \% \mathrm{~B} ; 10-13 \mathrm{~min}, 100 \% \mathrm{~B}$, and return to $30 \%$ in $13-15 \mathrm{~min}$. The flow rate of the mobile phase was $0.3 \mathrm{~mL} / \mathrm{min}$. Sample introduction and ionization were in the positive ion mode by electrospray ionization. We injected $1 \mathrm{uL}$ of each sample into the HPLC system.

\subsection{Validation of the Analytical Method}

The validation of the BIT analytical method was confirmed through linearity, recovery rate, and precision using a calibration curve and QC samples. All calibration curves were generated by a regression method of the peak area ratio among different concentrations of calibration standards. The coefficient of determination $\left(\mathrm{R}^{2}\right)$ for calibration curves ranged from 0.993 to 0.999 . The Method Detection Limit (MDL) was analyzed by the pre-treating standard, and the value of the lowest concentration was selected where the signal-to-noise ratio $(\mathrm{S} / \mathrm{N})$ of the detected analyte was 3 or more. The measured MDL value for BIT was $31.25 \mathrm{ng} / \mathrm{mL}$ at each blank matrix of receptor fluid sample, skin wash sample, tape strip sample, and skin deposit sample. 
BIT $\left(10 \mu \mathrm{g} / \mathrm{cm}^{2}\right.$ for a finite dose,

$100 \mu \mathrm{g} / \mathrm{cm}^{2}$ for infinite dose) applied to the donor chamber

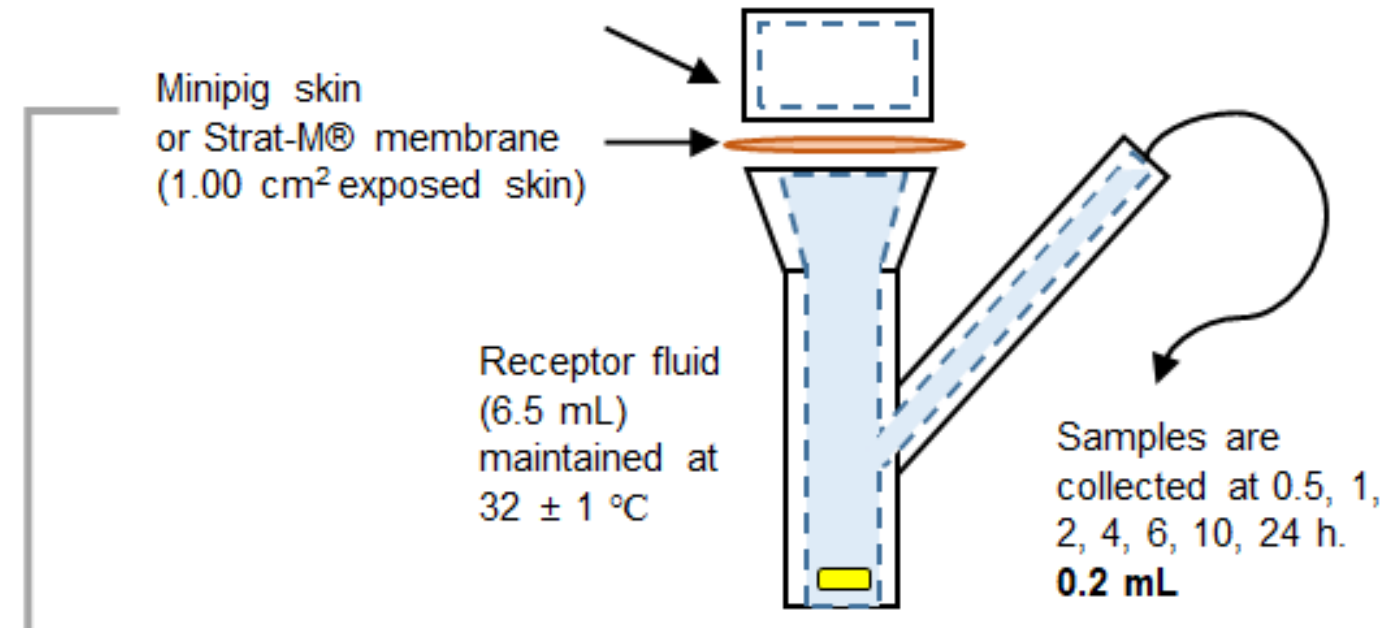

Donor chamber and skin washing

$\longrightarrow \begin{gathered}\text { Alcohol } \\ \text { swab }\end{gathered} \begin{gathered}\text { Alcohol } \\ \text { swab }\end{gathered}$

Skin tape

stripping
Skin cut in to 10 pieces

\section{Tape strips \\ X 10 times}

Into $50 \% \mathrm{MT}$ or $\mathrm{DW}(5 \mathrm{~mL})$

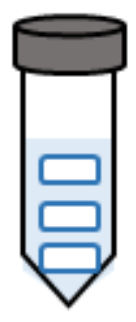

Into $50 \% \mathrm{MT}$ or $\mathrm{DW}(5 \mathrm{~mL})$
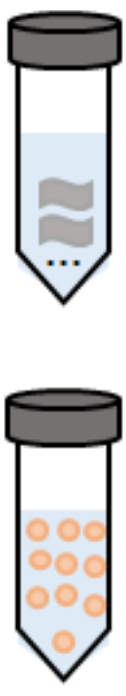

Each sample was sonicated for $1 \mathrm{~h}$, a same volume of MT added and centrifuged ( $13000 \mathrm{xg}, 10 \mathrm{~min}$ ).

Supernatant was filtered with a $0.22 \mu \mathrm{m}$ syringe filter before LCMS/MS analysis

Figure 1. Schematic diagram of percutaneous absorption study by Franz cell. BIT, benzisothiazolinone, MT, methanol, DW, distilled water.

For recovery rate and precision between days, the samples $(n=3)$ spiked in each blank matrix of receptor fluid sample, skin wash sample, tape strip sample, and skin 
deposit sample at concentrations of $62.5,125,250 \mu \mathrm{g} / \mathrm{L}$ were analyzed and performed on three consecutive days. The precision was expressed as a percentage of relative standard deviation (\% RSD).

\subsection{Absorption Parameters and Statistical Analysis}

Absorption data were plotted as a cumulative absorption-time curve per skin area. The steady-state flux $\left(\mathrm{J}_{\mathrm{ss}}\right)$ and lag time were determined from the linear portion of the curve. Determination of the start and upper boundaries of the linear range (i.e., steady-state conditions) was achieved according to the method shown by Niedorf et al. (2008) [28].

When using infinite-dose configurations in which the donor concentration $\left(C_{d}\right)$ far exceeds the concentration in the receptor fluid $\left(C_{a}\right)$, the permeation constant $\left(K_{p}, c m / h\right)$ was calculated by dividing the steady-state flux $\left(\mathrm{J}_{\mathrm{ss}}, \mathrm{ng} / \mathrm{cm}^{2} \cdot \mathrm{h}\right)$ by the concentration of the applied chemical $\left(\mathrm{C}_{\mathrm{d}}\right)$ as follows:

$$
\mathrm{Kp}=\frac{\mathrm{Jss}}{\mathrm{Cd}}
$$

For a finite dose, the flux could be normalized to be applied to the surface concentration relative absorption rate as an operational metric.

The mass distribution was expressed as a percentage of the applied dose calculated from the amount of chemical in each of the compartments of the diffusion cell in a finite dose. For the distribution profile, "skin wash" was the sum of the proportions of the dose recovered from the skin surface and donor chamber wash, and "tape strip" was the proportion of the dose recovered from the stratum corneum. "Skin deposit" was the proportion of the dose in both the epidermis and dermis after removal of the stratum corneum, and "receptor fluid" was the proportion of cumulative dose measured in the receptor fluid over $24 \mathrm{~h}$.

Results are presented as the arithmetic mean of three or four replicates \pm standard deviation (SD) or standard error (SE). Statistical analysis was performed using Excel 2016. Differences in skin permeation were evaluated by the Student's t-test between two datasets. Significance was determined by the $p$-value: ${ }^{*} p<0.05,{ }^{* *} p<0.01$.

\subsection{Systemic Exposure Estimation and Risk Assessment}

Systemic exposure dosage (SED) to the studied BITs via preservatives in cosmetics after applying the skincare product (cream, lotion, and essence) was estimated using the general equation [29]:

$$
\operatorname{SED}(\mathrm{mg} / \mathrm{kg} / \text { day })=\frac{\mathrm{D}(\mathrm{g} / \text { day }) \times 1000 \mathrm{mg} / \mathrm{g} \times \mathrm{C}(\mathrm{w} / \mathrm{v} \%) / 100 \times \mathrm{Ap}(\%) / 100}{\mathrm{BW}(\mathrm{kg})}
$$

SED: Systemic exposure dosage of BIT

D: Amount of product used daily

C: The maximum allowable concentration of BIT

AP: Experimentally obtained skin absorption rate of BIT at $10 \mathrm{~h}$ in each case BW: Average human body weight, $60 \mathrm{~kg}$

The risk was determined by comparing the margin of safety (MoS) to the target margin of safety obtained from the multiplication of uncertainty factors to account for the risks to humans. MoS was calculated by the following formula [29]:

$$
\mathrm{MoS}=\frac{\operatorname{NOAEL}(\mathrm{mg} / \mathrm{kg} \mathrm{bw} / \text { day })}{\operatorname{SED}(\mathrm{mg} / \mathrm{kg} \mathrm{bw} / \text { day })}
$$

When the MoS was greater than the target MoS, the adverse health risk of BIT was acceptable without harm under the current exposure levels. 


\section{Results}

3.1. Analytical Method Validation for the Receptor Fluid, Skin Wash, Tape Strip, and Skin Deposit Samples

The BIT retention time was $2.051 \mathrm{~min}$, and no interfering peaks were observed that hindered the analysis (Figure 2). The limit of detection (LOD) for BIT was 7.812 $\mu \mathrm{g} / \mathrm{L}$ and the limit of quantitation (LOQ) was $25.779 \mu \mathrm{g} / \mathrm{L}$. A typical calibration curve was obtained by the sample containing the standard solution, exhibiting good linearity $\left(\mathrm{R}^{2}>0.993\right)$. Furthermore, the calibration curve for the receptor fluid sample, skin washes, tape strips, and skin deposits showed good linearity from 31.25 to $500 \mathrm{ng} / \mathrm{mL}$. Inter-day recovery rate and precision were evaluated to determine the reliability of the current analytical method. Recoveries ranged from $97 \%$ to $106 \%$ and were consistent and reproducible in all cases. The precision values were between 1.17 and 14.04\%, meeting the criteria (within 15\%) of the Ministry of Food and Drug Safety Korea guidelines [30]. Therefore, the recovery rate and precision of the above-mentioned analytical conditions were appropriate for BIT analysis (Table 1).

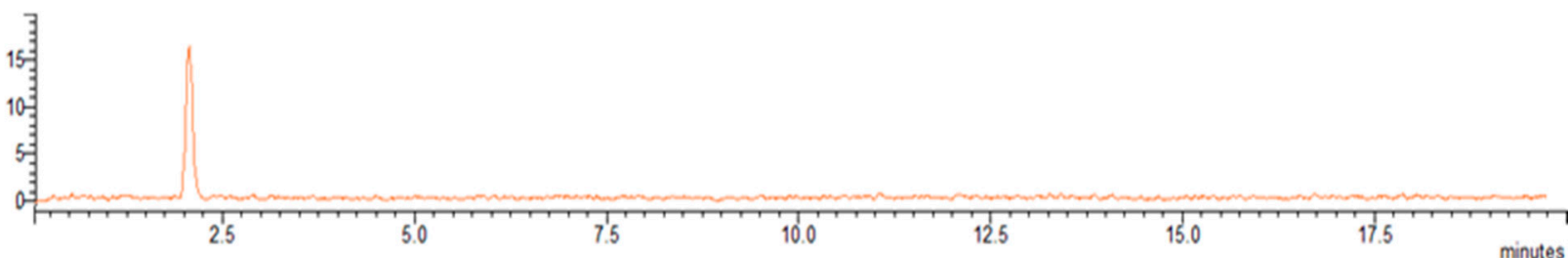

Figure 2. Chromatogram of BIT in the standard solution.

Table 1. The inter-day recovery rate and precision of BIT analysis.

\begin{tabular}{|c|c|c|c|}
\hline \multirow[b]{2}{*}{ Matrix } & \multirow[b]{2}{*}{ Concentration $(\mu g / L)$} & \multicolumn{2}{|c|}{ Inter-Day $^{\mathrm{a}}(n=3)$} \\
\hline & & $\begin{array}{l}\text { Recovery Rate } \\
\text { (Mean } \pm \text { SD) }\end{array}$ & $\begin{array}{l}\text { Precision } \\
\text { (\% RSD) }\end{array}$ \\
\hline \multirow{3}{*}{ Receptor fluid } & 62.5 & $97.59 \pm 13.70$ & 14.04 \\
\hline & 125 & $104.79 \pm 10.95$ & 10.45 \\
\hline & 250 & $100.64 \pm 0.68$ & 0.67 \\
\hline \multirow{3}{*}{ Skin Wash } & 62.5 & $101.14 \pm 5.33$ & 5.27 \\
\hline & 125 & $98.12 \pm 5.48$ & 5.59 \\
\hline & 250 & $106.14 \pm 3.03$ & 2.86 \\
\hline \multirow{3}{*}{ Tape strip } & 62.5 & $98.03 \pm 4.62$ & 4.71 \\
\hline & 125 & $103.20 \pm 4.16$ & 4.03 \\
\hline & 250 & $102.15 \pm 6.16$ & 6.03 \\
\hline \multirow{3}{*}{ Skin deposit } & 62.5 & $97.46 \pm 3.88$ & 3.98 \\
\hline & 125 & $100.16 \pm 1.17$ & 1.17 \\
\hline & 250 & $101.08 \pm 1.66$ & 1.64 \\
\hline
\end{tabular}

a Inter-day was evaluated for analysis on three consecutive days.

\subsection{Percutaneous Absorption of BIT Applied as an Infinite Dose through Minipig Skin or STRAT-M ${ }^{\circledR}$}

The cumulative skin permeation amounts of BIT with the minipig skin and Strat- $\mathrm{M}^{\circledR}$ are shown in Figure 3. BIT showed the cumulative absorption with $30.70 \pm 9.42 \mu \mathrm{g} / \mathrm{cm}^{2}$ (mean $\pm \mathrm{SE}$ ) in the minipig skin at $24 \mathrm{~h}$ was detected in the receptor fluid, while it showed $58.99 \pm 4.22 \mu \mathrm{g} / \mathrm{cm}^{2}$ in Strat- $\mathrm{M}^{\circledR}$. When comparing the permeation amounts between the minipig skin and Strat- $\mathrm{M}^{\circledR}$, BIT permeated higher in Strat- $\mathrm{M}^{\circledR}$ than in the minipig skin at all time-points. Additionally, BIT did not reach a steady-state in the minipig skin but reached a steady-state in Strat- $\mathrm{M}^{\circledR}$ at $6 \mathrm{~h}$. When comparing the results from the two models, BIT was significantly different at all time-points $(p<0.01$ at 1, 4, 6, and $10 \mathrm{~h}, p<0.05$ at 2 and $24 \mathrm{~h}$ ) except $0.5 \mathrm{~h}$. 


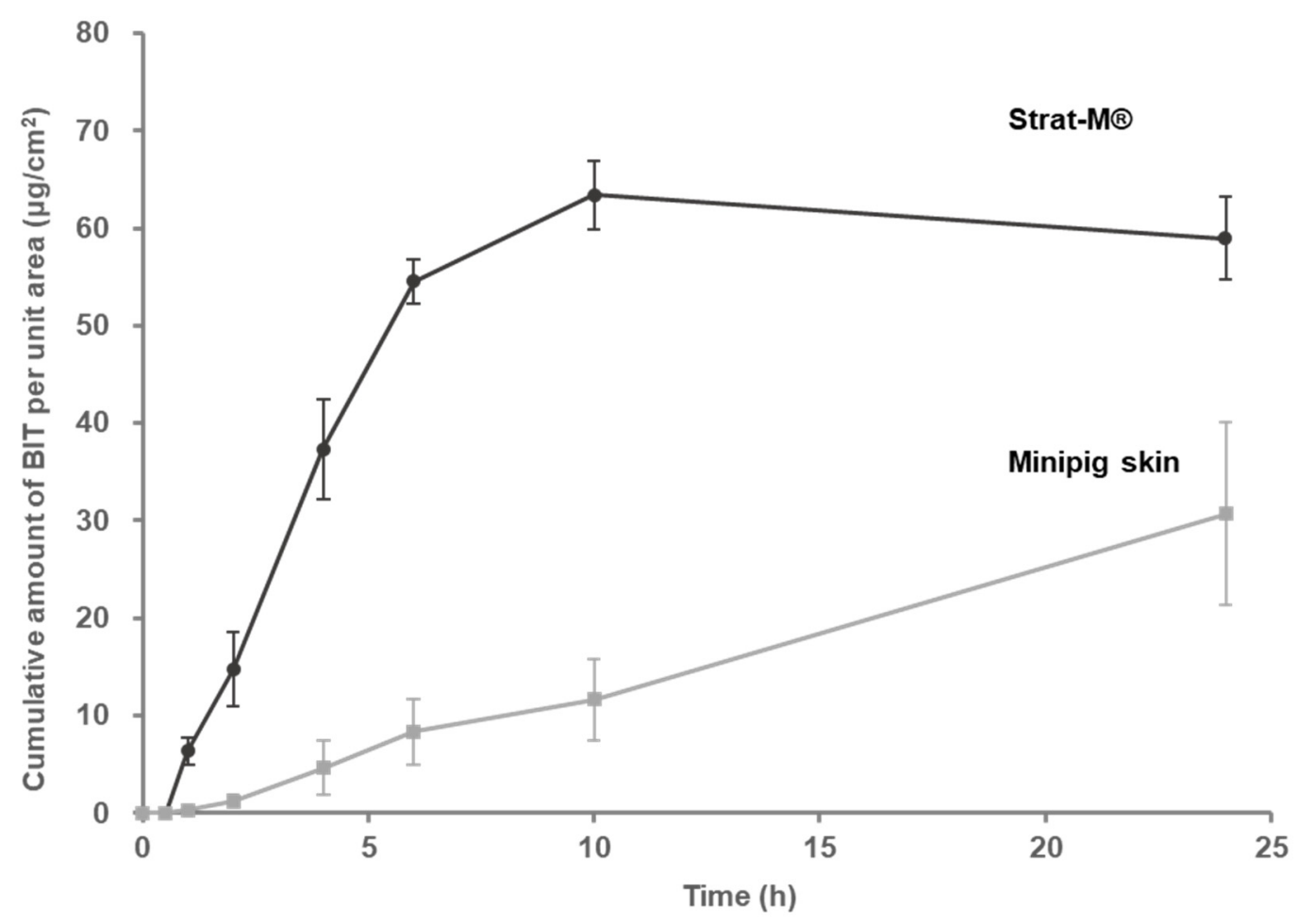

Figure 3. Cumulative absorption profile of BIT applied as an infinite dose $\left(100 \mu \mathrm{g} / \mathrm{cm}^{2}\right)$ for $24 \mathrm{~h}$. Upper, Strat-M ${ }^{\circledR}$ membrane, Lower, minipig skin $(300 \mu \mathrm{m})$. Values are mean $\pm \mathrm{SE}$ for four cells.

A plot of the cumulative absorbed amount of BIT $\left(\mu \mathrm{g} / \mathrm{cm}^{2}\right)$ against time (hours) was used to estimate the $\mathrm{J}_{\mathrm{ss}}\left(\mathrm{ng} / \mathrm{cm}^{2} \cdot \mathrm{h}\right)$ for the target compound and the $\mathrm{K}_{\mathrm{p}}(\mathrm{cm} / \mathrm{h})$ for the skins (Table 2). A test substance applied to the skin must partition into and diffuse through the skin before reaching the receptor fluid. This results in a lag-time with non-detectable flux. The lag time was represented by the time intercept of the regression line over the steadystate region of the permeation curve. The absorption of BIT was delayed with a lag time of $0.63 \mathrm{~h}$ in the minipig skin and $0.43 \mathrm{~h}$ in Strat- $\mathrm{M}^{\circledR}$. $\mathrm{J}_{\mathrm{ss}}$ was $1315 \mathrm{ng} / \mathrm{cm}^{2} \cdot \mathrm{h}$ for the minipig skin and $9969.9 \mathrm{ng} / \mathrm{cm}^{2} \cdot \mathrm{h}$ for Strat- $\mathrm{M}^{\circledR}$. This indicates that BIT showed higher skin permeability in Strat- $\mathrm{M}^{\circledR}$ compared to the minipig skin. The $K_{\mathrm{p}}$ value was $2.63 \times 10^{-3} \mathrm{~cm} / \mathrm{h}$ for the minipig skin and $19.94 \times 10^{-3} \mathrm{~cm} / \mathrm{h}$ for Strat- $\mathrm{M}^{\circledR}$. The permeation coefficient for BIT obtained with Strat- $\mathrm{M}^{\circledR}$ was 7.58 times higher than that of the minipig skin, indicating that the minipig skin is more resistant to BIT penetration than the Strat-M ${ }^{\circledR}$.

Table 2. Flux rates, permeation coefficients, lag times, and residual quantities of BIT applied to the skin surface in infinite doses $\left(100 \mu \mathrm{g} / \mathrm{cm}^{2}\right)$.

\begin{tabular}{lll}
\hline & Minipig Skin & Strat-M \\
\hline Flux $\left(\mathrm{J}_{\mathrm{ss}}\right)\left(\mathrm{ng} / \mathrm{cm}^{2} \cdot \mathrm{h}\right)$ & 1315 & 9969.9 \\
$\begin{array}{l}\text { Permeation coefficient }\left(\mathrm{K}_{\mathrm{p}}\right) \\
(\mathrm{cm} / \mathrm{h})\end{array}$ & $2.63 \times 10^{-3}$ & $19.94 \times 10^{-3}$ \\
Lag time $(\mathrm{h})$ & 0.63 & 0.43 \\
Linear range $(\mathrm{h})$ & $1-24$ & $0.5-6$ \\
$\begin{array}{l}\text { Residual quantity in skin at } 24 \mathrm{~h} \\
\left(\mu \mathrm{g} / \mathrm{cm}^{2}\right)\end{array}$ & $7.87 \pm 1.23$ & $1.74 \pm 0.51$
\end{tabular}

The parameters were calculated using the mean of cumulative absorption data obtained. Otherwise, values are mean \pm SE for 4 cells. 
3.3. Percutaneous Absorption of BIT Applied as a Finite Dose after Pretreating Cream, Lotion, and Essence through Minipig Skin

The cumulative permeation amount of BIT was evaluated using the minipig skin with or without the pretreatment of a finite dose of skincare products for 30 min (Figure 4). The $30 \mathrm{mg}$ dosage of skincare products was applied as the maximum amount of basic skincare products used on average per day for Koreans per the Korean Ministry of Food and Drug Safety. BIT in a finite-dose condition without any skincare products showed the lowest cumulative absorption with $3686.90 \pm 406.71 \mu \mathrm{g} / \mathrm{cm}^{2}$ at $24 \mathrm{~h}$ as detected in the receptor fluid. Higher amounts of $4137.83 \pm 267.67 \mu \mathrm{g} / \mathrm{cm}^{2}, 5925.13 \pm 416.61 \mu \mathrm{g} / \mathrm{cm}^{2}$, and $6395.16 \pm 295.18 \mu \mathrm{g} / \mathrm{cm}^{2}$ were observed for BIT after the pretreatment of cream, lotion, and essence, respectively. Overall, the cosmetics formulation with lower viscosity showed higher permeation. There was a significant difference in the permeated amounts of BIT between the lotion and the control groups in 4, 6, 10, and $24 \mathrm{~h}(p<0.05$ at 4, 6, and $24 \mathrm{~h}$, $p<0.01$ at $10 \mathrm{~h}$ ). There was also a significant difference between essence and control at 10 and $24 \mathrm{~h}(p<0.01)$, whereas no significant difference was found with the cream.

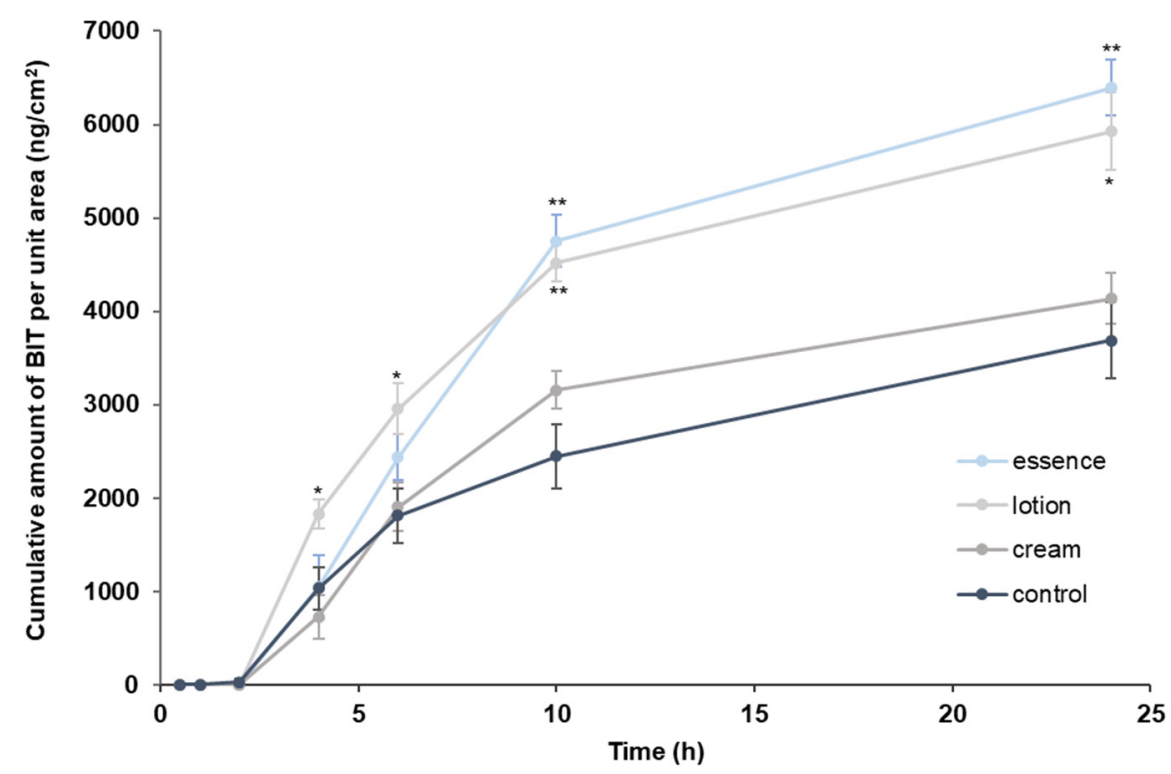

Figure 4. Cumulative absorption profile of BIT applied as a finite dose $\left(10 \mu \mathrm{g} / \mathrm{cm}^{2}\right)$ in minipig skin for $24 \mathrm{~h}$ after pretreating cosmetics $\left(30 \mathrm{~min}, 30 \mathrm{mg} / \mathrm{cm}^{2}\right)$. Values are mean $\pm \mathrm{SE}$ for 3 cells. ${ }^{*} p<0.05$, ** $p<0.01$ by Student's $t$-test.

The cumulative absorbed amount curve in Figure 4 was used to estimate the $\mathrm{J}_{\text {ss }}$ $\left(\mathrm{ng} / \mathrm{cm}^{2} \cdot \mathrm{h}\right)$ and the relative absorption rate $(\mathrm{cm} / \mathrm{h})$ for each case of BIT (Table 3). Steadystate flux and the relative absorption rate of the BIT were as follows: essence was greater than lotion, which was greater than cream, which was greater than the control.

Table 3. Flux rates, relative absorption rates, and lag times of BIT applied to the minipig skin surface in a finite dose $\left(10 \mu \mathrm{g} / \mathrm{cm}^{2}\right)$ after pretreating cosmetics $\left(30 \mathrm{~min}, 30 \mathrm{mg} / \mathrm{cm}^{2}\right)$.

\begin{tabular}{lllll}
\hline $\begin{array}{l}\text { Pretreated Skin } \\
\text { Care Product }\end{array}$ & $\begin{array}{l}\text { Flux }\left(\mathbf{J}_{\mathbf{s s}}\right) \\
\left(\mathbf{n g} / \mathbf{c m}^{2} \cdot \mathbf{h}\right)\end{array}$ & $\begin{array}{l}\text { Relative } \\
\text { Absorption rate } \\
\mathbf{( K p , ~ c m / h )}\end{array}$ & $\begin{array}{l}\text { Lag Time } \\
\mathbf{( h )}\end{array}$ & $\begin{array}{l}\text { Linear Range } \\
\mathbf{( h )}\end{array}$ \\
\hline $\begin{array}{l}\text { None (control) } \\
\text { Cream }\end{array}$ & 293.85 & 1.47 & 0.98 & $1-10$ \\
Lotion & 401.91 & 2.01 & 1.90 & $2-10$ \\
Essence & 545.08 & 2.73 & 1.23 & $2-10$ \\
\hline
\end{tabular}

The parameters were calculated using the mean of cumulative absorption data obtained. 
When the amounts of BIT in the skin wash, tape strips (SC), skin deposit, and receptor fluid (permeated amount) were examined at $24 \mathrm{~h}$ (Figure 5), a significantly large amount of BIT remained unabsorbed in the presence of cream. The pretreatment of lotion and essence resulted in a lower amount of BIT left in the skin wash than the control. Of note, BIT in the tape strips and skin deposits was significantly reduced by the pretreatment of all skincare products. In contrast, the amount of BIT absorbed into the receptor fluid was increased in the presence of all the skincare products. The total recovery of BIT was highest in the cream, while lotion and essence pretreated groups were similar to the control group, as shown in Figure 5.

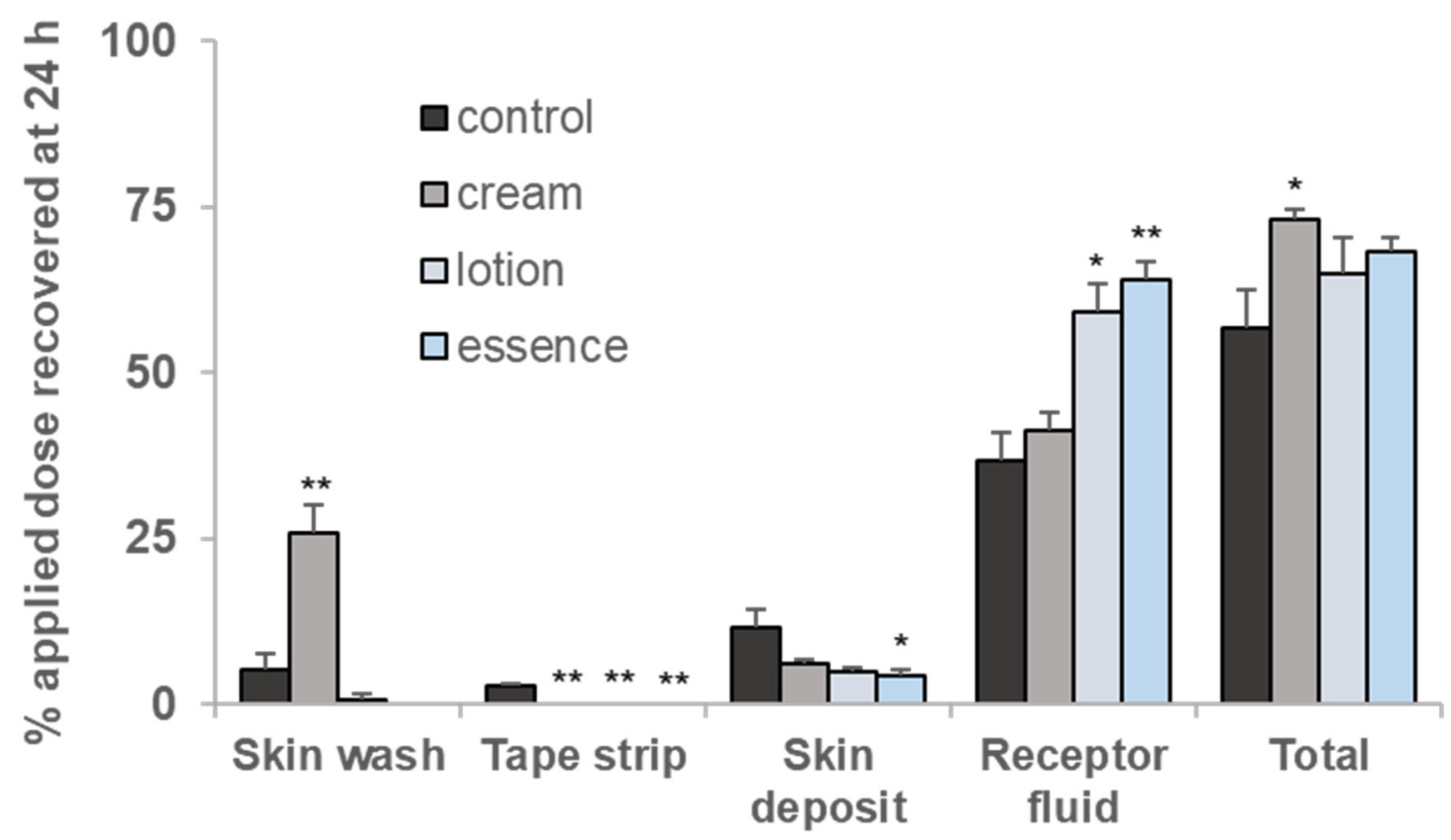

Figure 5. Distribution of BIT applied as a finite dose $\left(10 \mu \mathrm{g} / \mathrm{cm}^{2}\right)$ for $24 \mathrm{~h}$ after pre-treating cosmetics in minipig skin. Skin wash: the dose remaining on the skin surface and donor compartment, Tape strip: the dose in stratum corneum, Skin deposit: the deposit remaining in the skin after tape stripping, Receptor fluid: the dose in the receptor fluid, Total: sum of all the compartments. Values are mean \pm SE for 3 cells. ${ }^{*} p<0.05,{ }^{* *} p<0.01$ by Student's $t$-test.

\subsection{SED and MoS Calculation of BIT after Pretreatment with Cream, Lotion, and Essence}

We searched the results of BIT toxicity studies to conduct a risk assessment (Table 4). The NOAEL from a two-generation reproductive toxicity test in rats was $50 \mathrm{mg} / \mathrm{kg}$ [31]. The target MoS was calculated by applying uncertainty factors to produce a human risk assessment. The target MoS of BIT was 100, which was calculated by considering inter- and intra-species variation, exposure duration, and LOAEL to NOAEL conversion values [32].

Table 4. Summary of the toxicological evaluation for BIT reported by references.

\begin{tabular}{|c|c|c|c|c|c|c|c|}
\hline \multirow{2}{*}{$\begin{array}{l}\text { Study } \\
\text { Design }\end{array}$} & \multirow{2}{*}{$\begin{array}{l}\text { NOAEL } \\
\text { (mg/kg } \\
\text { bw/day) }\end{array}$} & \multicolumn{4}{|c|}{ Uncertainty Factor } & \multirow{2}{*}{ Target MoS } & \multirow{2}{*}{ Ref. } \\
\hline & & $\begin{array}{l}\text { Inter- } \\
\text { Species }\end{array}$ & $\begin{array}{l}\text { Intra- } \\
\text { Species }\end{array}$ & $\begin{array}{l}\text { Exposure } \\
\text { Duration }\end{array}$ & $\begin{array}{l}\text { LOAEL to } \\
\text { NOAEL }\end{array}$ & & \\
\hline $\begin{array}{l}\text { Rat, diet, two- } \\
\text { generation }\end{array}$ & 50 & 10 & 10 & 1 & 1 & 100 & {$[31,32]$} \\
\hline
\end{tabular}

NOAEL: no-observed-adverse-effect level, Target MoS: target margin of safety.

The SED (systemic exposure dose) values from cosmetic use when all cosmetics contain BIT were summarized in Table 5 . SED was calculated by obtaining the absorption rate at 
$10 \mathrm{~h}$ as observed in Figure 4, which was increased when there was a pre-treated skincare product (control < cream < lotion < essence). MoS values were determined to be 1092.41, 762.76, and 725.82 for cream, lotion, and essence pretreatment, respectively, which were all smaller than the control but larger than the target MoS of 100.

Table 5. Risk assessment of BIT in the presence of skincare products.

\begin{tabular}{|c|c|c|c|c|c|}
\hline $\begin{array}{l}\text { Pretreated } \\
\text { Skin Care } \\
\text { Product }\end{array}$ & $\begin{array}{l}\text { Total } \\
\text { Amount of } \\
\text { Cosmetic } \\
\text { Products } \\
\text { Used Daily } \\
\text { (g/day) }\end{array}$ & $\begin{array}{l}\text { BIT Conc. } \\
(\%)\end{array}$ & $\begin{array}{l}\text { Estimated } \\
\text { Dermal } \\
\text { Absorption } \\
\text { Rate after } 10 \\
\text { h }(\%)\end{array}$ & $\begin{array}{l}\text { SED (mg/kg } \\
\text { bw/day) * }\end{array}$ & MoS \\
\hline $\begin{array}{l}\text { None } \\
\text { (control) }\end{array}$ & & & $24.45 \pm 3.39$ & $35.46 \times 10^{-3}$ & 1410.15 \\
\hline Cream & $17.4^{*}$ & 0.05 & $31.57 \pm 2.00$ & $45.77 \times 10^{-3}$ & 1092.41 \\
\hline Lotion & & & $45.21 \pm 2.01$ & $65.55 \times 10^{-3}$ & 762.76 \\
\hline Essence & & & $47.51 \pm 2.80$ & $68.89 \times 10^{-3}$ & 725.82 \\
\hline
\end{tabular}

\section{Discussion}

Here, we aimed to use in vitro approaches to determine the profile of percutaneous absorption of BIT using a minipig skin and Strat- $\mathrm{M}^{\circledR}$ membrane based on OECD Test guidance 428. The Franz cell model, used to determine the cumulative dose per area of compound across the skin, is an alternative method widely applied to study transdermal absorption of various dermatological products, including cosmetics, chemicals, and drugs [34]. Suitable operational conditions and discriminative criteria of the Franz cell diffusion process have been well-evaluated [35].

BIT is one of the most commonly used isothiazolinone compounds. The permeation coefficient $\left(\mathrm{K}_{\mathrm{p}}\right)$ of BIT was calculated as the percutaneous penetration index when an infinite dose was applied. The relative absorption rate was obtained when a finite dose was applied, which showed a similar pattern with the $K_{p} . K_{p}$ estimates vary widely between the respective estimation methods. There are several mathematical models for $\mathrm{K}_{\mathrm{p}}$ prediction, such as PACEM-KD. According to Lian et al. (2008), the PACEM-KD model, which includes $\mathrm{a} \mathrm{K}_{\mathrm{ow}}$ factor in its prediction equation, performed the best among several dermal mathematical permeability models for a large experimental dataset to assess the skin permeability of biocides (124 chemical compounds) [10,36]. The calculated $\mathrm{K}_{\mathrm{p}}$ value of BIT according to the simulation model was $0.505 \times 10^{-3} \mathrm{~cm} / \mathrm{h}$ [10], which is about 5.21 times lower than the measured $K_{p}$ value of $2.63 \times 10^{-3} \mathrm{~cm} / \mathrm{h}$ at the infinite concentration in our study. The reason for the difference in $\mathrm{K}_{\mathrm{p}}$ values was that the data obtained only by calculation has uncertainty compared to that obtained by the experiment [10]. The $\mathrm{K}_{\mathrm{p}}$ values for BIT have not yet been experimentally precisely measured. Our study has contributed to predicting an accurate $K_{p}$ value.

We compared the skin permeation values between a minipig skin and Strat- $\mathrm{M}^{\circledR}$ using infinite doses. Pig skin is a reliable substitute for human skin, and it is frequently used in skin absorption experiments. Gerstel et al. (2016) found that human skin and pig skin showed similar distribution and bioavailability profiles in chemical permeation studies, suggesting that pig skin is a good substitute for human skin [37]. Strat- $\mathrm{M}^{\circledR}$ is an artificial synthetic, non-animal-based model for transdermal diffusion testing that is predictive of diffusion in human skin without stability and storage limitations [38]. Arce Jr et al. [39] compared the permeability of caffeine and rhododendrol between minipig skin and Strat$\mathrm{M}^{\circledR}$ using Franz cells. The cumulative dose of each membrane was similar under the finite-dose condition. In contrast, we found that both the steady-state flux and permeation coefficient of Strat-M ${ }^{\circledR}$ was 7.58 times higher than those obtained with the minipig skin 
for BIT. This may be because Strat- $\mathrm{M}^{\circledR}$ does not mimic the heterogeneous complexity of SCs, which are highly organized intercellular structures, and fails to simulate barrier properties similar to those of the SC to provide the ideal interaction of vehicles with SC lipids [39]. Assessment of BIT permeation in infinite-dose conditions with the use of Strat$\mathrm{M}^{\circledR}$ could be misleading by overestimating the permeation parameters. Therefore, the usefulness of Strat- $\mathrm{M}^{\circledR}$ in an absorption experiment may be limited only to identifying the qualitative tendencies.

We selected isopropyl alcohol for the vehicle of BIT, since it has been widely used for dermal permeation studies [27,40], and BIT was highly soluble and stable in it (data not shown). Moore et al. suggested that isopropyl alcohol is a volatile amphipathic solvent which volatilizes rapidly from the skin surface and mimics "real-life" exposure of the skin to droplets of chemicals released into the air [27]. This may be ideal for the study of dermal permeation of biocides including BIT since biocides are often used as spray forms [41]. However, significant evaporation of isopropyl alcohol and resultant crystallization of BIT may be occurring on the skin surface, especially in a finite-dose application, which may decrease the availability of BIT to permeate the skin $[42,43]$. Therefore, we consider that further studies are necessary to examine the vehicle effects on the dermal permeation of BIT in the future.

When cream, lotion, and essence were pre-treated, the cumulative absorption dose was significantly increased compared to that of the control $(31.57 \pm 2.00 \%, 45.21 \pm 2.01 \%$, $47.51 \pm 2.80 \%$, respectively for cream, lotion, and essence vs control, $24.45 \pm 3.39 \%$ ), which indicates that the chemicals can be absorbed more easily into the skin in the presence of skincare products. Since the amounts of BIT in the tape strips were greatly reduced when the skincare products were present (Figure 5), this suggests that skincare products may interfere with the barrier function of the stratum corneum. Skincare products contain various components, like surfactants, alcohols, polyols, and essential oils which can affect the barrier function of the stratum corneum and function as chemical permeation enhancers [44]. Pont et al. [45] showed that the dermal penetration of a herbicide, 2,4dichlorophenoxyacetic acid through hairless mouse skin in $24 \mathrm{~h}$ increased from $54.9 \pm 4.7 \%$ to $86.9 \pm 2.5 \%$ in the presence of padimate-o-containing sunscreen, while Wang and $\mathrm{Gu}$ [46] and Yiin et al. [47] demonstrated that the use of sunscreen, oxybenzone after application of a repellent, and DEET (N,N-diethyl-m-toluamide) increases the absorption of DEET through human skin. Along with these studies, our results corroborate that caution shall be given to the concurrent uses of cosmetics and potentially toxic chemicals.

Interestingly, the total amounts of BIT recovered in the skin wash, tape strips (SC), skin deposit, and receptor fluid (permeated amount) at $24 \mathrm{~h}$ were well-below $100 \%$ for all groups. We suspect that since BIT is a thiol reactive isothiazolinone [48], some portion of it may have reacted with cysteine residues of the skin, lowering the total recovery rate. To verify this hypothesis, further study with radiolabeled BIT would be necessary.

To predict a more specific risk to humans, we calculated the SED for each exposure case (Table 5). Since the average residence time of the substances adhered to the skin is $12 \mathrm{~h}$ [49], the absorption rate at $12 \mathrm{~h}$ had to be substituted for SED. Although there no data were obtained at $12 \mathrm{~h}$, the absorption rate at $10 \mathrm{~h}$ was used, as this was the longest time value in the linear range. Risk assessment needs to consider a variety of foreseeable exposure conditions and even worst-case exposure conditions at high concentrations and high doses, so $0.05 \%$ was used for the BIT concentration, as this is the highest allowable concentration. We employed two different BIT concentration levels of (I) $0.05 \%(w / v)$ for the infinite dose and (II) $0.02 \%(w / v)$ for the finite-dose condition to assess the skin absorption rate of BIT. As the maximum approved concentration of BIT is $0.05 \%$, we believe that the BIT concentration employed is within the same range as the worst-case exposure scenario with respect to its risk to human health. However, possible under-estimation of skin absorption in real-life exposure scenarios where lower concentrations of BIT are used could not be excluded, since dermal exposure to lower concentration of chemicals may lead to higher dermal absorption [50]. Nevertheless, our data indicates that BIT is highly 
absorbed dermally as compared to the conservative skin absorption default value of $50 \%$ in the case of absence of data as described in SCCS guidance, indicating that the margin of increases in skin absorption at lower concentrations may be minimal.

According to the SCCS, $17.4 \mathrm{~g} /$ day, the total human exposure to cosmetics of all categories [33] was substituted into the amount of BIT used daily and further calculated into $\mathrm{SED}(\mathrm{mg} / \mathrm{kg}$ bw/day) using the obtained skin absorption rates. As a result of conducting the risk assessment with the above values, the risk priority was higher in the presence of essence as compared to lotion, which was higher than cream, which was higher than the control. Nevertheless, all the margin of safety values was greater than the target MoS. BIT is safe in the dermal exposure pathway. However, MoS was significantly lowered with skincare product pretreatment, so the effects on other skincare products or substances harmful to the skin other than BIT must be studied.

Collectively, we established the dermal permeation profiles of BIT using a minipig skin and Strat- $\mathrm{M}^{\circledR}$, an artificial membrane. BIT was more permeable to Strat-M ${ }^{\circledR}$ than the minipig skin $\left(\mathrm{K}_{\mathrm{p}}, \mathrm{cm} / \mathrm{h}, 2.63 \times 10^{-3}\right.$ and $19.94 \times 10^{-3}$, respectively). Dermal absorption of BIT was relatively high $(24.45 \pm 3.39 \%$ at $10 \mathrm{~h}$ application on the untreated minipig skin). We also demonstrated that BIT was more permeable in the presence of cosmetics, while the amount in the stratum corneum and skin deposit was reduced. However, the risk assessment for the dermally applied BIT in the absence or presence of cosmetics revealed that all of the margins of safety values obtained were greater than 100 . We believe that this research may contribute to a greater understanding of the risk assessment of isothiazolinone biocides.

Supplementary Materials: The following supporting information can be downloaded at: https: / / www.mdpi.com/article/10.3390/toxics10030108/s1, Table S1: Formulation of cream pretreated at minipig skin, Table S2: Formulation of lotion pretreated at minipig skin, Table S3: The formulations of essence pretreated at minipig skin.

Author Contributions: Conceptualization, Y.H. and K.-M.L.; methodology, Y.H., D.-H.L. and D.C.; formal analysis, Y.H. and D.-H.L.; data curation, Y.H.; writing-original draft preparation, Y.H.; writing-review and editing, K.-M.L. and D.C.; supervision, K.-M.L. and D.C.; project administration, K.-M.L. and D.C.; funding acquisition, K.-M.L. and D.C. All authors have read and agreed to the published version of the manuscript.

Funding: This work was supported by the Korea Environment Industry \& Technology Institute (KEITI) through the Technology Program for Establishing Biocide Safety Management (or Project), funded by the Korea Ministry of Environment (MOE) (2020002970001, 2021002970001, 1485017976).

Institutional Review Board Statement: Not applicable.

Informed Consent Statement: Not applicable.

Data Availability Statement: The data presented in this study are available on request from the corresponding author.

Conflicts of Interest: The authors declare no conflict of interest.

\section{References}

1. Williams, T.M. The mechanism of action of isothiazolone biocide. In Proceedings of the CORROSION 2006, San Diego, CA, USA, 12 March 2006.

2. Berthet, A.; Spring, P.; Vernez, D.; Plateel, G.; Hopf, N.B. Ex vivo human skin permeation of methylchloroisothiazolinone (MCI) and methylisothiazolinone (MI). Arch. Toxicol. 2017, 91, 3529-3542. [CrossRef] [PubMed]

3. Friis, U.F.; Menné, T.; Flyvholm, M.A.; Bonde, J.P.E.; Lepoittevin, J.P.; Le Coz, C.J.; Johansen, J.D. Isothiazolinones in commercial products at Danish workplaces. Contact Dermat. 2014, 71, 65-74. [CrossRef] [PubMed]

4. Paulus, W. Relationship between chemical structure and activity or mode of action of microbicides. In Directory of Microbicides for the Protection of Materials: A Handbook; Springer Science \& Business Media: Berlin/Heidelberg, Germany, $2005 ;$ pp. 10-12.

5. Alexander, B. An assessment of the comparative sensitization potential of some common isothiazolinones. Contact Dermat. 2002, 46, 191-196. [CrossRef] [PubMed] 
6. Silva, V.; Silva, C.; Soares, P.; Garrido, E.M.; Borges, F.; Garrido, J. Isothiazolinone biocides: Chemistry, biological, and toxicity profiles. Molecules 2020, 25, 991. [CrossRef] [PubMed]

7. Ackermann, L.; Aalto-Korte, K.; Alanko, K.; Hasan, T.; Jolanki, R.; Lammintausta, K.; Lauerma, A.; Laukkanen, A.; Liippo, J.; Riekki, R. Contact sensitization to methylisothiazolinone in Finland-A multicentre study. Contact Dermat. 2011, 64, 49-53. [CrossRef] [PubMed]

8. Alvarez-Rivera, G.; Dagnac, T.; Lores, M.; Garcia-Jares, C.; Sanchez-Prado, L.; Lamas, J.P.; Llompart, M. Determination of isothiazolinone preservatives in cosmetics and household products by matrix solid-phase dispersion followed by high-performance liquid chromatography-tandem mass spectrometry. J. Chromatogr. A 2012, 1270, 41-50. [CrossRef]

9. Herman, A.; Aerts, O.; de Montjoye, L.; Tromme, I.; Goossens, A.; Baeck, M. Isothiazolinone derivatives and allergic contact dermatitis: A review and update. J. Eur. Acad. Dermatol. Venereol. 2019, 33, 267-276. [CrossRef]

10. Garcia-Hidalgo, E.; Schneider, D.; von Goetz, N.; Delmaar, C.; Siegrist, M.; Hungerbühler, K. Aggregate consumer exposure to isothiazolinones via household care and personal care products: Probabilistic modelling and benzisothiazolinone risk assessment. Environ. Int. 2018, 118, 245-256. [CrossRef]

11. Hwang, J.-H.; Jeong, H.; Jung, Y.-O.; Nam, K.T.; Lim, K.-M. Skin irritation and inhalation toxicity of biocides evaluated with reconstructed human epidermis and airway models. Food Chem. Toxicol. 2021, 150, 112064. [CrossRef]

12. Novick, R.M.; Nelson, M.L.; Unice, K.M.; Keenan, J.J.; Paustenbach, D.J. Estimation of the safe use concentrations of the preservative 1,2-benzisothiazolin-3-one (BIT) in consumer cleaning products and sunscreens. Food Chem. Toxicol. 2013, 56, 60-66. [CrossRef]

13. Meysman, T.; Goossens, A. Occupational allergic contact dermatitis caused by benzisothiazolinone in printing ink and soap Contact Dermat. 2017, 76, 51-53. [CrossRef] [PubMed]

14. Lee, N.; Jang, D.Y.; Lee, D.H.; Jeong, H.; Nam, K.T.; Choi, D.W.; Lim, K.M. Local Toxicity of Biocides after Direct and Aerosol Exposure on the Human Skin Epidermis and Airway Tissue Models. Toxics 2021, 9, 29. [CrossRef] [PubMed]

15. Hahn, S.; Schneider, K.; Gartiser, S.; Heger, W.; Mangelsdorf, I. Consumer exposure to biocides-identification of relevant sources and evaluation of possible health effects. Environ. Health 2010, 9, 1-11. [CrossRef] [PubMed]

16. Pereira, R.F.; Barrias, C.C.; Granja, P.L.; Bartolo, P.J. Advanced biofabrication strategies for skin regeneration and repair. Nanomedicine 2013, 8, 603-621. [CrossRef]

17. Refai, H.; Müller-Goymann, C.C. The influence of dilution of topical semisolid preparations on hydrocortisone permeation through excised human stratum corneum. Eur. J. Pharm. Biopharm. 2002, 54, 143-150. [CrossRef]

18. SCCS. SCCS Notes of Guidance for the Testing of Cosmetic Substances and Their Safety Evaluation (8th Revision). 2012. Available online: http:/ / ec.europa.eu/health/scientific_committees/consumer_safety/docs/sccs_s_006.pdf (accessed on 20 February 2022).

19. Hormann, A.M.; Vom Saal, F.S.; Nagel, S.C.; Stahlhut, R.W.; Moyer, C.L.; Ellersieck, M.R.; Welshons, W.V.; Toutain, P.-L.; Taylor J.A. Holding thermal receipt paper and eating food after using hand sanitizer results in high serum bioactive and urine total levels of bisphenol A (BPA). PLoS ONE 2014, 9, e110509. [CrossRef]

20. Pawar, G.; Abdallah, M.A.-E.; de Sáa, E.V.; Harrad, S. Dermal bioaccessibility of flame retardants from indoor dust and the influence of topically applied cosmetics. J. Expo. Sci. Environ. Epidemiol. 2017, 27, 100-105. [CrossRef]

21. Karande, P.; Mitragotri, S. Enhancement of transdermal drug delivery via synergistic action of chemicals. Biochim. Biophys. Acta BBA-Biomembr. 2009, 1788, 2362-2373. [CrossRef]

22. McCulley, L.; Cheng, C.; Mentari, E.; Diak, I.-L.; Michele, T. Alcohol-based hand sanitizer exposures and effects on young children in the US during the COVID-19 pandemic. Clin. Toxicol. 2021, 59, 355-356. [CrossRef]

23. OECD. 428: Skin absorption: In vitro Method. In OECD Guidelines for the Testing of Chemicals, Section 4; OECD Publishing: Paris, France, 23 November 2004.

24. Hwang, J.H.; Jeong, H.; Lee, N.; Hur, S.; Lee, N.; Han, J.J.; Jang, H.W.; Choi, W.K.; Nam, K.T.; Lim, K.M. Ex Vivo Live FullThickness Porcine Skin Model as a Versatile In Vitro Testing Method for Skin Barrier Research. Int. J. Mol. Sci. 2021, $22,657$. [CrossRef]

25. Bolla, P.K.; Clark, B.A.; Juluri, A.; Cheruvu, H.S.; Renukuntla, J. Evaluation of formulation parameters on permeation of ibuprofen from topical formulations using Strat- $\mathrm{M}^{\circledR}$ membrane. Pharmaceutics 2020, 12, 151. [CrossRef] [PubMed]

26. Uchida, T.; Kadhum, W.R.; Kanai, S.; Todo, H.; Oshizaka, T.; Sugibayashi, K. Prediction of skin permeation by chemical compounds using the artificial membrane, Strat-M ${ }^{\mathrm{TM}}$. Eur. J. Pharm. Sci. 2015, 67, 113-118. [CrossRef] [PubMed]

27. Moore, C.; Wilkinson, S.; Blain, P.; Dunn, M.; Aust, G.; Williams, F. Percutaneous absorption and distribution of organophosphates (chlorpyrifos and dichlorvos) following dermal exposure and decontamination scenarios using in vitro human skin model. Toxicol. Lett. 2014, 229, 66-72. [CrossRef] [PubMed]

28. Niedorf, F.; Schmidt, E.; Kietzmann, M. The automated, accurate and reproducible determination of steady-state permeation parameters from percutaneous permeation data. Altern. Lab. Anim. 2008, 36, 201-213. [CrossRef]

29. Sung, C.R.; Kim, K.-B.; Lee, J.Y.; Lee, B.-M.; Kwack, S.J. Risk assessment of ethylhexyl dimethyl PABA in cosmetics. Toxicol. Res. 2019, 35, 131-136. [CrossRef]

30. MFDS. Guideline on Bioanalytical Method Validation. 2014. Available online: https://www.mfds.go.kr/brd/m_210/down.do? brd_id=data0010\&seq=13054\&data_tp=A\&file_seq=1 (accessed on 26 September 2020). 
31. SCCS. Opinion on Benzisothiazolinone COLIPA no P96. 2012. Available online: https://ec.europa.eu/health/archive/ph_risk/ committees/sccp/documents/out289_en.pdf (accessed on 15 June 2017).

32. Pack, E.C.; Lee, H.G.; Jang, D.Y.; Sin, H.S.; Kim, T.Y.; Kim, H.S.; Lim, K.M.; Choi, D.W. Probabilistic risk assessment of preservatives in dishwashing detergents and wet wipes for Korean consumers. Sci. Total Environ. 2021, 782, 146829. [CrossRef]

33. SCCS. SCCS Notes of Guidance for the Testing of Cosmetic Ingredients and Their Safety Evaluation 11th Revision, 30-31 March 2021, SCCS/1628/21. 2021. Available online: https://ec.europa.eu/health/sites/default/files/scientific_committees/consumer_ safety/docs/sccs_o_250.pdf (accessed on 20 February 2022).

34. Neupane, R.; Boddu, S.H.; Renukuntla, J.; Babu, R.J.; Tiwari, A.K. Alternatives to biological skin in permeation studies: Current trends and possibilities. Pharmaceutics 2020, 12, 152. [CrossRef]

35. Seo, J.-E.; Kim, S.; Kim, B.-H. In vitro skin absorption tests of three types of parabens using a Franz diffusion cell. J. Expo. Sci. Environ. Epidemiol. 2017, 27, 320-325. [CrossRef]

36. Lian, G.; Chen, L.; Han, L. An evaluation of mathematical models for predicting skin permeability. J. Pharm. Sci. 2008, 97, 584-598 [CrossRef]

37. Gerstel, D.; Jacques-Jamin, C.; Schepky, A.; Cubberley, R.; Eilstein, J.; Grégoire, S.; Hewitt, N.; Klaric, M.; Rothe, H.; Duplan, H. Comparison of protocols for measuring cosmetic ingredient distribution in human and pig skin. Toxicol. In Vitro 2016, 34, 153-160. [CrossRef]

38. Del Gaudio, P.; Russo, P.; Dorado, R.R.; Sansone, F.; Mencherini, T.; Gasparri, F.; Aquino, R.P. Submicrometric hypromellose acetate succinate particles as carrier for soy isoflavones extract with improved skin penetration performance. Carbohydr. Polym. 2017, 165, 22-29. [CrossRef] [PubMed]

39. Arce Jr, F.; Asano, N.; See, G.L.; Itakura, S.; Todo, H.; Sugibayashi, K. Usefulness of artificial membrane, Strat-M ${ }^{\circledR}$, in the assessment of drug permeation from complex vehicles in finite dose conditions. Pharmaceutics 2020, 12, 173. [CrossRef]

40. Ossowicz, P.; Klebeko, J.; Janus, E.; Nowak, A.; Duchnik, W.; Kucharski, Ł.; Klimowicz, A. The effect of alcohols as vehicles on the percutaneous absorption and skin retention of ibuprofen modified with l-valine alkyl esters. RSC Adv. 2020, 10, 41727-41740. [CrossRef]

41. Song, J.; Jung, K.J.; Yang, M.J.; Han, S.C.; Lee, K. Assessment of acute and repeated pulmonary toxicities of oligo(2-(2ethoxy)ethoxyethyl guanidium chloride in mice. Toxicol. Res. 2021, 37, 99-113. [CrossRef] [PubMed]

42. Santos, P.; Watkinson, A.; Hadgraft, J.; Lane, M. Oxybutynin permeation in skin: The influence of drug and solvent activity. Int. J. Pharm. 2010, 384, 67-72. [CrossRef]

43. Oliveira, G.; Hadgraft, J.; Lane, M.E. The influence of volatile solvents on transport across model membranes and human skin. Int. J. Pharm. 2012, 435, 38-49. [CrossRef]

44. Barry, B.W. Novel mechanisms and devices to enable successful transdermal drug delivery. Eur. J. Pharm. Sci. 2001, 14, 101-114. [CrossRef]

45. Pont, A.R.; Charron, A.R.; Brand, R.M. Active ingredients in sunscreens act as topical penetration enhancers for the herbicide 2,4-dichlorophenoxyacetic acid. Toxicol. Appl. Pharm. 2004, 195, 348-354. [CrossRef]

46. Wang, T.; Gu, X. In vitro percutaneous permeation of the repellent DEET and the sunscreen oxybenzone across human skin. $J$. Pharm. Pharm. Sci. 2007, 10, 17-25.

47. Yiin, L.M.; Tian, J.N.; Hung, C.C. Assessment of dermal absorption of DEET-containing insect repellent and oxybenzonecontaining sunscreen using human urinary metabolites. Env. Sci. Pollut. Res. Int. 2015, 22, 7062-7070. [CrossRef]

48. Collier, P.J.; Ramsey, A.; Waigh, R.D.; Douglas, K.T.; Austin, P.; Gilbert, P. Chemical reactivity of some isothiazolone biocides. J Appl. Bacteriol. 1990, 69, 578-584. [CrossRef] [PubMed]

49. Baltazar, M.T.; Cable, S.; Carmichael, P.L.; Cubberley, R.; Cull, T.; Delagrange, M.; Dent, M.P.; Hatherell, S.; Houghton, J.; Kukic, P. A next-generation risk assessment case study for coumarin in cosmetic products. Toxicol. Sci. 2020, 176, 236-252. [CrossRef] [PubMed]

50. Kissel, J.C. The mismeasure of dermal absorption. J. Expo. Sci. Environ. Epidemiol. 2011, 21, 302-309. [CrossRef] [PubMed] 